\title{
ПРОЗОВИЙ ДОРОБОК КАРСОН МАККАЛЛЕРС ЯК ОБ'СКТ РЕЦЕПЦІї
}

\author{
Мандзюк Р. С.
}

\section{ВСТУП}

Однією 3 найбільш оригінальних представниць літературного процесу другої половини XX ст. вважається американська письменниця Карсон МакКаллерс (1917-1967). У цьому зв'язку заслуговує на увагу оцінка відомого англійського письменника й драматурга Г. Гріна (19041991): «МакКаллерс i, можливо, ще Фолкнер - єдині справжні письменники $з$ часу смерті Д.Г. Лоренса з оригінальною поетичною чутливістю. Я віддаю перевагу МакКаллерс, а не Фолкнеру, оскільки вона пише більш чітко; я віддаю перевагу ӥй, а не Д.Г. Лоренсу, оскільки вона позбавлена пафосу» ${ }^{1}$ У каноні американського мистецтва доробок К. МакКаллерс посів чільне місце 3 огляду на продовження традицій прози «південної готики» ${ }^{2}$. При цьому іiі творчість вирізняється винятковою тонкістю й поетичністю образів, що сприяло неодноразовій кінематографічній та телевізійній адаптації текстів авторки роману «Відблиски в золотому оці».

В американській літературі доробок митців, які репрезентують «південну школу», постає самобутнім явищем. Про їі окремішнє вагоме значення в розвитку американського письменства свідчить тяглість літературної традиції Півдня, витоки якої припадають на початок XIX століття. Прагнення майстрів слова виразити трагічне відчуття розпаду взаємозв'язку «Я-особи» та соціуму втілилось в особливу систему образів. В іiі носіях химерно поєднується сила духу 3 жорстокістю поведінки та ганебними вчинками. Тому патетичний тон нарації нерідко змінюється гротескністю образів та саркастичністю. Умовний світ гротеску, в якому в загостреному й перебільшеному вигляді за допомогою несподіваних поєднань віддзеркалюються кардинальні протиріччя буття людини, виступає межовим узагальненням сутності певного негативного явища, про яке той чи інший автор оповідає своєму реципієнту. Така форма художнього

${ }^{1}$ Gray R. Review of The Lonely Hunter: A Biography of Carson McCullers, by Virginia Spencer Carr. Journal of American Studies. August 1978. Vol. 12. No. 2. P. 247.

${ }_{2}$ Bloom H. The American canon: literary genius from Emerson to Pynchon / ed. by David Mikics. New York : The Library of America, 2019. 426 p. 
зображення проступає передусім у творах В. Фолкнера (1897-1962), Т. Вулфа (1900-1938), Е.П. Колдвелл (1903-1987), Р.П. Воррена (19051989), а також у прозі представниць літератури післявоєнного покоління - Ф. О'Коннор (1925-1964) та К. МакКаллерс. Їхні твори, що побачили світ після 1945 року, засвідчили актуальність «південної» проблематики, викладеної в оновленому трактуванні й у другій половині XX століття.

\section{1. Рецепція прози К. МакКаллерс у періодиці}

Художня манера К. МакКаллерс стала предметом дослідницьких зацікавлень з боку англомовних критиків та літературознавців ще наприкінці 50-х рp. XX ст., коли в авторитетному часописі «Сауз Атлантік Квотерлі» (“The South Atlantic Quarterly”) 1957 року вийшла друком стаття «Бог та Безбожжя в творі «Серце - самотній мисливець» Ф. Дергема ${ }^{3}$. Відтоді до популяризації творчості мисткині спричинилися публікації на шпальтах таких видань, як «Атлантік Манслі», «Джорджія рів'ю», «Саузвест рів'ю», «Література та психологія», «Саузерн Г'юменітіз рів'ю», «Кентакі рів'ю», «Букс еброуд», «Експлікатор», «Дескант», «Міссіссіпі Квотерлі: журнал південних культур», «Бакнелл рів'ю», «Нью Райтерс Дайджест», «Вірджінія Квотерлі», «Пемброк Мегезін», «Кенедіен рів’ю оф Амерікен стадіз», «Нью Орлеанс рів'ю», «Нью-Йоркер». При цьому особливістю рецепції художніх устремлінь К. МакКаллерс $\epsilon$ динамічний перехід від їхнього критично-публіцистичного до наукового осмислення.

Авторитетний американський літературознавець Л. Фідлер (19172003) свого часу відзначив: «Наше письменство - це не просто втеча від фізичних даних реального світу в пошуках (безстатевого і тьмяного) Ідеалу; від Чарльза Брокдена Брауна до Вільяма Фолкнера або Юдори Велті, Пола Боулза чи Джона Гоукса - це, що бентежить, готична література, нереалістична та негативна, садистська та мелодраматична, іншими словами, література темряви та гротеску в країні світла та урочистих завірень». ${ }^{4}$ У цей ряд названих постатей органічно вписується й ім'я К. МакКаллерс. Тому й закономірно, що значний обсяг наукових публікацій, спрямований на вивчення творчості письменниці, опирається на висвітлення гротескного мислення як вагомого складника iї поетики. Спробу окреслити засоби реалізації та

\footnotetext{
${ }^{3}$ Durham F. God and No God in The Heart is a Lonely Hunter. The South Atlantic Quarterly. Fall 1957. No. 56. P. 494-499.

${ }^{4}$ Fiedler L. Love and Death in the American Novel. Normal, Il. : Dalkey Archive Press, 1997. P. 28-29.
} 
функції гротеску в прозі здійснили Р.М. Райхнітц («Невдале кохання: гротеск у двох романах Карсон МакКаллерс», 1968) («Моральна функція спотворення в південному гротеску», 1972) П. Нагпал («Елемент гротеску у творах «Відблиски в золотому оці» та «Балада про невеселий шинок» Карсон МакКаллерс», 1987) ${ }^{7}$, Е. Карлтон («Поза готикою та гротеском: феміністичний погляд на три жіночі персонажі Карсон МакКаллерс», 1988) ${ }^{8}$, Ф. Кестлер («Готичний вплив гротескних персонажів «Самотнього мисливця», 1988) ${ }^{9}$, С. Глісон-Вайт («Перегляд південного гротеску: Михайло Бахтін і випадок Карсон МакКаллерс», 2001) ${ }^{10}$, М. Фрі («Пониження і заколот: чудернацькість, гротеск і мовчання у творчості Карсон МакКаллерс», $2008)^{11}$, К. Белл («Гротескні зустрічі з підлітковим віком: прочитання твору «Учасниця весілля» Карсон МакКаллерс», 2011) ${ }^{12}$. Як засвідчує аналіз, питання про природу гротеску як естетичної категорії та способи його втілення в художніх текстах американської авторки й досі залишаються актуальними.

Вагомий пізнавальний інтерес викликають дослідження різних соціокультурних складників у творчій лабораторії К. МакКаллерс крізь призму компаративного аналізу, що сприяє глибшому розкриттю сутнісних рис іiі письма. Стильову уподібненість художньої світобудови К. МакКаллерс, 3 одного боку, та представників американської (С. Льюїс, К.Е. Портер, Ю.Е. Велті, Дж. Болдвін, Ф. О’Коннор, Т. Моррісон, Е. Вокер), англійської (Д.Г. Лоуренс, М. Дреббл), данської (К. Бліксен творила під псевдонімом Ісак Дінесен), російської (Ф. Достоєвський, Л. Толстой) літератур з іншого, увиразнили Р.С. Філліпс («Мавпа» Дінесен та «Балада»

${ }^{5}$ Rechnitz R.M. The Failure of Love: The Grotesque in Two Novels by Carson McCullers. Georgia Review. 1968. Winter. P. 454-463.

${ }^{6}$ Presley D.E. The Moral Function of Distortion in Southern Grotesque. South Atlantic Bulletin. 1972. No. 37:2. P. 37-46.

${ }^{7}$ Nagpal P. The Element of Grotesque in Reflections in a Golden Eye and Ballad of the Sad Cafe by Carson McCullers. Panjab University Research Bulletin. 1987. October. No. 18:2. P. 61-66.

${ }^{8}$ Carlton A. Beyond Gothic and Grotesque: A Feminist View of Three Female Characters of Carson McCullers. Pembroke Magazine. 1988. No. 20. P. 54-62.

${ }^{9}$ Kestler F. Gothic Influence of the Grotesque Characters of the Lonely Hunter. Pembroke Magazine. 1988. No. 20. P. 54-62.

${ }^{10}$ Gleeson-White S. Revisiting the Southern Grotesque: Mikhail Bakhtin and the Case of Carson McCullers. Southern Literary Journal. Spring 2001. No. 33. P. 108-124.

${ }^{11}$ Free M. Relegation and Rebellion: The Queer, the Grotesque, and the Silent in the Fiction of Carson McCullers. Studies in the novel. 2008. Vol. 40. No. 4. P. 426-446.

${ }^{12}$ Bell K. Grotesque Encounters with Adolescence: Reading Carson McCullers' The Member of the Wedding. Changing English. 2011. Vol. 18. No. 1. P. 67-73. 
МакКаллерс: дослідження літературної близькості», $1964^{13}$, Т. Пахмусс («Достоєвський, Д.Г. Лоуренс та Карсон МакКаллерс: впливи та поєднання», 1974) 14 , Г.Ч. Співак («Три феміністичні прочитання: МакКаллерс, Дреббл, Габермас», 1979) ${ }^{15}$, Л. Губерт («До питання про творчість Вокер: спадщина кохання Карсон МакКаллерс», 1988) ${ }^{16}$, С. Глісон-Вайт («Своєрідна південна форма потворності: Юдора Велті, Карсон МакКаллерс та Фланнері О'Коннор», 2003) ${ }^{17}$, К. Гроба, Дж. Крайслер, Е.С. Катлер («Іван Ілліч у законах Джима Кроу: Карсон МакКаллерс і Лев Толстой», 2004) ${ }^{18}$, Е. Матлок-Зіманн («Південні казки: «Принцеса» Кетрін Енн Портер та «Балада про невеселий шинок» Карсон МакКаллерс», 2007) ${ }^{19}$, Е. Барретт («Дивовижна людяність» у творах «Серце - самотній мисливець» Карсон МакКаллерс та «Інша країна» Джеймса Болдвіна», 2011) ${ }^{20}$, П. Тершвелл, Н. Гарлей («Мертві хлопчики та дівчата-підлітки: відгалуженість від роману виховання у творах «Учасниця весілля» Карсон МакКаллерс та «Сула» Тоні Моррісон», 2012) ${ }^{21}$, Б. Сакстон («Пошук «Ідіота» Достоєвського у романі «Серце - самотній мисливець» Карсон МакКаллерс», 2013) 22, В. Кайзер («Мікрополітика фашизму у творах «Серце - самотній мисливець» Карсон МакКаллерс

${ }^{13}$ Phillips R.S. Dinesen's "Monkey" and McCullers' "Ballad": A Study in Literary Affinity. Studies in Short Fiction. 1964. No. 1. P. 184-190.

${ }^{14}$ Pachmuss T. Dostoevsky, D.H. Lawrence, and Carson McCullers: Influences and Confluences. Germano-Slavica: A Canadian Journal of Germanic and Slavic Comparative Studies. 1974. No. 4. P. 59-68.

${ }^{15}$ Spivak G.Ch. Three Feminist Readings: McCullers, Drabble, Habermas. Union Seminary Quarterly Review. 1979-1980. No. 35. P. 1-2.

16 Hubert L. To Alice Walker: Carson McCullers' Legacy of Love. Pembroke Magazine. 1988. No. 20. P. 89-95.

${ }^{17}$ Gleeson-White S. A Peculiarly Southern Form of Ugliness: Eudora Welty, Carson McCullers, and Flannery O'Connor. Southern Literary Journal. Fall 2003. Vol. 36. P. 46-57.

${ }^{18}$ Groba C.G., Crisler J.S., Cutler E.S. Ivan Ilych in the Jim Crow South: Carson McCullers and Leo Tolstoy. Literature and belief; Belief in the modernist age: a symposium on major novelists. Brigham Young University, 2004. March. P. 117-134.

${ }^{19}$ Matlok-Ziemann E. Southern Fairy Tales: Katherine Anne Porter's "The Princess" and Carson McCullers's "The Ballad of the Sad Café". The Mississippi quarterly. 2007. Vol. 60. No. 2. P. 257-272.

${ }^{20}$ Barrett E. The "Astonishing Humanity" of Carson McCullers' The Heart is a Lonely Hunter and James Baldwin's Another Country. American Notes and Queries. 2011. Vol. 24. No. 4. P. 216-226.

${ }^{21}$ Thurschwell P., Hurley N. Dead Boys and Adolescent Girls: Unjoining the Bildungsroman in Carson McCullers's The Member of the Wedding and Toni Morrison's Sula. English studies in Canada. 2012. Vol. 38. No. 3/4. P. 105-128.

${ }^{22}$ Saxton B. Finding Dostoevsky's "Idiot" in Carson McCullers's The Heart Is a Lonely Hunter. American Notes and Queries. 2013. Vol. 26. No. 2. P. 103-108. 
та «У нас це неможливо» Сінклера Льюїса», 2014)². Завдяки цим зіставленням більш цілісно проступають властивості й якості художніх досягнень мисткині, які й окреслюють інструменти розбудови їі власної творчої самоідентифікації.

К. МакКаллерс як самобутній письменниці вдалося виробити в процесі творчого самовизначення жанрові модифікації, які доцільно розглядати в тісній сполуці з їі художньою манерою, проблематикою та поетикою творів. Знакове місце в цьому контексті посіли зразки малої прози. На особливості іiі формально-змістових модифікацій вказали Дж.Т. Мур («Балада про невеселий шинок» МакКаллерс», 1970) ${ }^{24}$, Д. Едмондс («Листування»: оповідка «Забутий» Карсон МакКаллерс», $1972)^{25}$, Д.Ф. Гайллард («Присутність оповідача у «Баладі про невеселий шинок» Карсон МакКаллерс», 1972) ${ }^{26}$, Дж. МакНаллі («Інтроспективний оповідач у «Баладі про невеселий шинок», 1973) $)^{27}$, М. Волш («Анти-казка Карсон МакКаллерс: «Балада про невеселий шинок», 1988) ${ }^{28}$, Е. Белл («Щасливі предмети та жорстокий оптимізм в оповідці «Листування» Карсон МакКаллерс», 2019) ${ }^{29}$. Твори К. МакКаллерс прийнято розглядати в річищі «південної готики», що певною мірою обмежує уявлення ії доробок. Полівимірність текстів мисткині - це іiі шлях до діалогу з потенційним реципієнтом, що поєднав у собі минувшину і сучасність, духовний досвід поколінь, глибинні пласти американської культури, активізацію варіативних жанрових форм. Отже, дослідження питання жанрових модифікацій та їхніх ознак не втрачає свого злободенного звучання.

Продуктивним у рецепції творчості К. МакКаллерс став підхід, що грунтується на інтерпретації гендерних та расових стереотипів. Він представлений публікаціями, зокрема, таких учених, як П.Р. Броутон («Відмова від жіночності у «Баладі про невеселий шинок» Карсон

${ }^{23}$ Kaiser W. The Micropolitics of Fascism in Carson McCullers's The Heart Is a Lonely Hunter and Sinclair Lewis's It Can't Happen Here. Genre. 2014. Vol. 47. No. 3. P. 285-308.

${ }^{24}$ Moore J.T. McCullers' The Ballad of the Sad Cafe. Explicator. 1970. No. 29. Item 27. P. 51.

${ }^{25}$ Edmonds D. Correspondence': A "Forgotten" Carson McCullers Short Story. Studies in Short Fiction. 1972. No. 9. P. 89-92.

${ }^{26}$ Gaillard D.F. The Presence of the Narrator in Carson McCullers' The Ballad of the Sad Cafe. Mississippi Quarterly. 1972. No. 25. P. 419-427.

${ }^{27}$ McNally J. The Introspective Narrator in The Ballad of the Sad Cafe. South Atlantic Bulletin. 1973. No. 38:4. P. 40-44.

28 Walsh M. Carson McCullers' anti-fairytale: "The Ballad of the Sad Café". Pembroke Magazine. 1988. No. 20. P. 43-49.

29 Bell E. Happy objects and cruel optimism in Carson McCullers' story "Correspondence". Short fiction in theory and practice. 2019. Vol. 9. No. 2. P. 117-127. 
МакКаллерс», 1974) $)^{30}$, Е. Гінсберг («Тема жіночої ініціації в американській літературі», 1975) ${ }^{31}$, К. Сосноскі («Фріки суспільства: наслідки сексуальних стереотипів у творчості Карсон МакКаллерс», $1988)^{32}$, Р.К. Мартін («Стать, раса та колоніальне тіло: «Філіппінський хлопчик» Карсон МакКаллерс...», 1992) 33 , К.Г. Гонзалез («Нестерпний тягар жіночності у творах «Учасниця весілля» та «Балада про невеселий шинок» Карсон МакКаллерс», 1994) $)^{34}$, К. Дейвіс, В.Дж. Фрі («Річ відома і невимовна: сексуальна відмінність у творі «Учасниця весілля» Карсон МакКаллерс», 1995) $)^{35}$, Л. Файн («Гендерні конфлікти та їхні «темні» проєкції...», 1998) $)^{36}$, С. Ву («Розширення південної білості: реконцептуалізація етнічної відмінності в малій прозі Карсон МакКаллерс», 2001) ${ }^{37}$. Виопуклення цього аспекту в прозі письменниці має закономірну основу. Адже вона виступає не тільки проти усталених стереотипів, але й нерідко шокує читача оригінальністю сюжетної лінії.

\section{2. Тенденції сприйняття творчості К. МакКаллерс}

Підвищена зосередженість дослідників на осмисленні тих художніх явищ, які притаманні доробку К. МакКаллерс, у рамках спільних наукових проєктів спостерігається на зламі XX - початку XXI ст. Однак поштовхом до їхньої появи можна вважати монографію колективного характеру, що побачила світ ще 1974 року на європейському континенті. Сталося це завдяки ініціативі Г. Гаффманса. Швейцарський видавець та літературний редактор упорядкував німецькомовну книжку під

${ }^{30}$ Broughton P.R. Rejection of the Feminine in Carson McCuller's The Ballad of the Sad Cafe. Twentieth Century Literature. 1974. No. 20. P. 33-43.

${ }^{31}$ Ginsberg E. The Female Initiation Theme in American Fiction. Studies in American Fiction. 1975. No. 3. P. 27-37.

${ }^{32}$ Sosnoski K. Society's Freaks: The Effects of Sexual Stereotyping in Carson McCullers' Fiction. Pembroke Magazine. 1988. No. 20. P. 82-88.

${ }^{33}$ Martin R.K. Gender, race, and the colonial body: Carson McCullers's Filipino boy, and David Henry Hwang's... Canadian Review of American Studies. Fall 1992. Vol. 23. No. 1. P. 95-107.

${ }^{34}$ Gonzalez C.G. The Intolerable Burden of Femininity in Carson McCullers' The Member of the Wedding and the Ballad of the Sad Cafe. Atlantis: Revista de la Associacion Espanola de Estudios Anglo Norteamericanos. 1994. May-Nov. No. 16: 1-2. P. 133-148.

${ }^{35}$ Davis K., Free W.J. A Thing Known and Not Spoken: Sexual Difference in Carson McCullers Member of the Wedding. The Journal of the Comparative Drama Conference. 1995. No. 16. P. 39-42.

${ }^{36}$ Fine L. Gender Conflicts and Their "Dark" Projections in Coming of Age White Female Southern Novels. Southern Quarterly. Summer 1998. No. 38. P. 121-130.

${ }^{37}$ Wu C. Expanding Southern Whiteness: Reconceptualizing Ethnic Difference in the Short Fiction of Carson McCullers. Southern Literary Journal. 2001. Vol. 34. Part 1. P. 44-55. 
недвозначною назвою «Про Карсон МакКаллерс» ${ }^{38}$. Примітною $\epsilon$ грунтовна передмова, яку підготувала для цього видання сестра мисткині М.Г. Сміт (1922-1983), редакторка художньої літератури часопису «Мадмуазель» упродовж 1943-1960. Власне, її заслуги у справі популяризації творів К. МакКаллерс важко переоцінити. Передусім тут слід згадати про упорядковану нею збірку малої прози «Закладене серце», що вийшла друком уже після смерті іï авторки 1972 року. Передмова М.Г. Сміт служить містком до сприйняття інших складників книжки. Зокрема, тут подано низку есеїв, спогадів та нотаток письменниці: «Погляньте на вітчизну, американці!» (1940), «Мій квартал - Бруклін» (1941), «Ми несли наші прапори - ми теж були пацифістами» (1941), «Російські реалісти та південна література» (1941), «Наші голови - похилені» (1945), «Як я розпочинала писати» (1948), «Самотність - американська хвороба» (1949), «Співпережите бачення» (1950), «Квітуча мрія: нотатки про письмо» (1959), «На славу сяючому блиску: Ісак Дінесен» (1963). У цьому ключі примітною є заувага авторки в есеї «Квітуча мрія: нотатки про письмо», в якому вона поділилась одним із секретів своєї творчої лабораторії: «Я стаю героями, про яких пишу. Я настільки занурена в них, що їхні мотиви - мої власні. Коли я пишу про злодія, я ним стаю; коли я пишу про Капітана Пендертона, я стаю гомосексуалістом, коли пишу про глухонімого, я німію на час оповіді. Я стаю героями, про яких пишу, і славлю латинського поета Теренція, який сказав: «...ніщо людське мені не чуже» ${ }^{39}$. Така прив'язаність до власних творінь - химерних і дивакуватих персонажів - наділяс образи певною розкутістю в реалізації свого призначення. Своєю чергою ексцентричність протагоністів авторка пояснює їхнім перебуванням у просторі особливої реальності, створеної «3 мови, голосів та листяного орнаменту» ${ }^{40}$. Загалом, вивчення документалістики письменниці дає підстави дійти висновку: ці праці формують самостійне відгалуження творчості К. МакКаллерс не тільки 3 історичною, але й художньою цінністю.

Г. Гаффманс зібрав у книжці матеріали мемуарного характеру, нариси, рецензії про К. МакКаллерс. Своєрідністю композиції видання $\epsilon$ саме різножанровість текстів, а також те, що всі шістнадцять авторів роздумів безпосередньо належали до знакових учасників літературного та громадського життя другої половини XX століття. 3-поміж них Д. Паркер， Е. Шнак， В.С. Прітчетт， Г.Е. Клерман， Р. Райт， М.В. Янг,

\footnotetext{
${ }^{38}$ Über Carson McCullers / Hrsg. von G. Haffmans. Zürich : Diogenes, 1974. $221 \mathrm{~s}$.

${ }^{39}$ McCullers C. The mortgaged heart... / ed. by M.G. Smith. London : Barrie and Jenkins, 1972. P. 282.

${ }^{40}$ там само.
} 
Т. Вільямс, Г.М. Брем, Г. Відал, З. Ленц, Д. Латтманн, Е.Ф. Олбі, Г.М. Енценсбергер, Г. Воман, Г. Фукс, Е. О’Браєн. Їхні спостереження, як самобутній прояв специфічного дискурсу мемуаристики XX століття, відкрили перспективи наукового вивчення творчості К. МакКаллерс. У цьому зв'язку примітною є різноплановість наукової парадигми видання, яке увібрало важкодоступні для широкого загалу тексти. При цьому не йдеться про їхню рівноцінність у плані висвітлення літературно-естетичних поглядів мисткині. Грунтовне розкриття отримали окремі аспекти доробку К. МакКаллерс: жанровостилістичні особливості малої прози (Д. Латтманн, В.С. Прітчетт, Г. Фукс), романів «Відблиски в золотому оці» (Г. Воман, Т. Вільямс), «Годинник без стрілок» (Г.М. Енценсбергер, Д. Паркер), драм (Г. Клерман), химерність (Е. О’Браєн, Е. Олбі), метафізичність універсалій (М. Янг) прози, взаємозв'язки протагоністів із навколишнім середовищем (Р. Райт, Г. Відал, З. Ленц). Вагому роль у викладі власного бачення характерних рис художньої манери К. МакКаллерс відіграв чинник особистого знайомства, що вилилось у публіцистичні вкраплення, побудовані на зверненні до спогадів. Ознаки хрестоматійного мемуарного тексту має праця Е. Шнак під назвою «Мої спогади про Карсон». Загалом, строкатість інтерпретаційного ракурсу демонструє багатий потенціал пізнання творчої лабораторії американської письменниці. Попри те, що матеріали позначені властивою творчим особистостям суб'єктивністю, яка проступає зі світоглядних тверджень і суспільних установок, вони містять змістовну оцінку мистецької стратегії К. МакКаллерс на різних етапах творчості, фактів їі життя та літературних явищ другої половини XX століття.

Аналіз рецептивних моделей доробку К. МакКаллерс дає можливість ідентифікувати як спільні, так і амбівалентні ознаки у цьому процесі. Адже структура iï художніх текстів вибудовує простір для вироблення різновекторних інтерпретацій. Свідченням цього $\epsilon$ вихід друком 1986 року книжки «Карсон МакКаллерс» ${ }^{41}$ у серії «Сучасні критичні погляди» за редакцією Г. Блума (1930-2019). У вступі визначний американський літературний критик і культуролог наголосив: «Усі персонажі МакКаллерс виказують особливу химерність у здійсненні здатності кохати - вони існують i, врештірешт, згасають, закохуючись у безнадійну надію» ${ }^{42}$. Таке «загальне прагнення до любові», попри можливу загибель, Г. Блум порівняв

${ }^{41}$ Carson McCullers / ed. by Harold Bloom. New York : Chelsea House Publishers, 1986. 159 p.

${ }^{42}$ Bloom H. Introduction. Carson McCullers / ed. by Harold Bloom. New York : Chelsea House Publishers, 1986. P. 2. 
3 психоаналітичним виміром еротичної ілюзії в трактуванні 3. Фройда. Автор праці «Західний канон: книги на тлі епох» (1994) запропонував читачеві випробувану концепцію, коли видання охоплює матеріали знакових для певної епохи особистостей. Свої критичні нариси в антології оприлюднили такі постаті, як М.В. Янг («Метафізична оповідь»), Т. Вільямс («Ця книжка: «Відблиски в золотому оці»), Г. Відал («Годинник без стрілок» Карсон МакКаллерс»), О. Еванс («Досягнення Карсон МакКаллерс»), К. Лубберс («Необхідне замовлення»), Л. Гравер («Наполегливе завзяття: ранні романи МакКаллерс»), Р.М. Кук («Відблиски в золотому оці»), Р. Грей («Настрої та нестатки»), М.Б. МакДовелл («Мала проза та поеми»), Л. Вестлінг («Амазонське жахіття Карсон МакКаллерс»), М.Е. Дейзі («Два голоси одного оповідача в «Баладі про невеселий шинок»), Б.А. Вайт («Втрата тожсамості в «Учасниці весілля»). Усі вони обгрунтовують місце творчості К. МакКаллерс в американському літературному каноні. При цьому такого висновку деякі 3 названих дослідників дійшли ще за життя письменниці. Так, приміром, німецький американіст К. Лубберс ще 1963 року виокремив як узагальнену тему доробку К. МакКаллерс зображення «проблематичного й болісного існування людини на тлі різних відхилень від іiі правильного курсу» ${ }^{43}$.

1996 року Б.Л. Кларк та М. Фрідмен підготували до друку збірник наукових праць «Критичні есеї на пошану Карсон МакКаллерс» ${ }^{44}$. Він став своєрідним підсумком досліджень знавців творчої спадщини письменниці наприкінці XX століття. Контекст інтерпретації пї творів розширили в нарисах «Карсон МакКаллерс та Південь» Д.Е. Преслі, «Карсон МакКаллерс: естетика болю» Л.Д. Рубін, «Випадок Карсон МакКаллерс» О. Еванс, «Феміністичне читання: «Серце - самотній мисливець» МакКаллерс» Г.Ч. Співак, «Карсон МакКаллерс, самотня мисливиця» Г. МакФерсон, «У боротьбі за життя» С.М. Гілберт, С. Губар, «Дівчатка-бешкетниці і збурена жіночність» Л. Вестлінг, «Матеріалістичне читання твору «Годинник без стрілок» С.П. Гейвлі, «Приголомшливе: мала проза Карсон МакКаллерс» Р. Філліпс, «Дві планетарні системи» Р. Олдрідж, «Балада про невеселий шинок» Карсон МакКаллерс: недоспівана, жінконенависницька та «згуртовуюча» пісня» С.М. Паулсон, «Стирання «ми 3 мене» і переписування расового сценарію: двоє учасників «Весілля» Карсон МакКаллерс» Т.М. Дейвіс,

${ }^{43}$ Lubbers K. The Necessary Order: A Study of Theme and Structure in Carson McCullers' Fiction. Jahrbuch für Amerikastudien. 1963. Bd. 8. P. 203.

${ }^{44}$ Critical Essays on Carson McCullers; / ed. by B.L. Clark, M. Friedman. New York : Hall, 1996. 240 p. 
«Гомероеротика та людські відносини: прочитання Карсон МакКаллерс «як лесбійки» Л.Дж. Кеншафт. Крім цих текстів, тут містяться також критичні огляди романів «Серце - самотній мисливець» (Р. Райт, М. Сартон, Дж. Саймонс), «Відблиски в золотому оці» (Дж. Еджі, Р. Філд), «Учасниця весілля» (Дж. Денджерфілд, М. Янг), «Годинник без стрілок» (І. Гоу, Р. Годден, Д. Паркер, П. Мортімер), малої прози (В.П. Кленсі, В.С. Прітчетт, Н. Гордімер, М. Фрідмен), п’єс (Дж.М. Браун, К. Тайнен, Р. Гейс). Примітним є твердження М. Янг, яка в своїй оцінці окреслила К. МакКаллерс «поетичним символістом, шукачем тих світлих значень, які завжди перевищують межі стереотипного, загальноприйнятого та так званого нормального» ${ }^{45}$. При цьому більшість дослідників підкреслюе домінанту гротескного принципу зображення в прозі К. МакКаллерс.

Різноманітні критичні прийоми 3 метою визначення особливостей взаємодії художнього письма К. МакКаллерс із сучасними соціальними структурами запропонували редактори видання «Карсон МакКаллерс у XXI столітті» ${ }^{46}$ Е. Грегем-Бертоліні та К. Кайсер. Названий збірник можна окреслити новаторським у рецепції творчості К. МакКаллерс 3 огляду на грунтовне наукове осмислення нових архівних матеріалів, які були передані Колумбійському університету після смерті в 2013 році Мері Мерсер, психіатра та приятельки письменниці. 3-поміж цих матеріалів неабиякою цінністю позначені стенограми психіатричних сеансів з 1958 року. Головний задум упорядників полягав у пошуку відповіді на запитання, яким чином ії художні та документальні тексти резонують з потенційним реципієнтом на відстані часу. Цю концепцію реалізували, крім Е. Грегем-Бертоліні та К. Кайсер, К. Девс, М.М. Шеразі, Я. Вітт, К.Т. Скеггс, К. Мегом, Р.К. Гугленд, Т. Говен, К. Прел, М. Матцуі, С. Роунтрі, Л. Бін, Б.Р. Ріко, К. Словен. Їхні розвідки служать підтвердженням того факту, що доробок К. МакКаллерс характеризується контамінацією різних жанрових елементів i міжжанровою взаємодією. Адже ідейно-естетичні настанови епохи на зламі XX - початку XXI століть диктували мисткині потребу пошуку нових жанрових підходів 3 проєкцією на поєднання художніх засобів.

Однією 3 перших монографій, присвячених рецепції творчих устремлінь письменниці, стала праця «К. МакКаллерс, iї життя

45 Young M. Metaphysical Fiction. Critical Essays on Carson McCullers / ed. by B.L. Clark, M. Friedman. New York : Hall, 1996. P. 34.

46 Carson McCullers in the twenty-first century / ed. by A. Graham-Bertolini, C. Kayser. Cham : Palgrave Macmillan, 2016. 279 p. 
й творчість» (1965) ${ }^{47}$ О.В. Еванса (1915-1981). Американський учений зробив вдалу спробу відтворити повну й достовірну картину всіх етапів життєвого й творчого шляху письменниці на основі дослідження максимально широкої кількості джерел. Слід відзначити, що ще 1962 року в своїй статті «Досягнення Карсон МакКаллерс» О. Еванс назвав іiі «найкращим алегоричним письменником по цей бік Атлантики 3 часів Готорна та Мелвілла» ${ }^{48}$. Сутність цієї оцінки полягає в тому, що К. МакКаллерс закладає у свій наратив притчевість, яка майстерно вбудована в реалістичний рівень оповіді. Розвідки біографічного характеру продовжили Д. Едмондс ${ }^{49}$ та Л. Гравер ${ }^{50}$. Таким чином, уже в 60-х рр. XX ст. образ та особистість К. МакКаллерс були вписані в американський історико-культурний процес.

Зібраний у науковій рецепції матеріал станом на 1980 рік каталогізували й осмислили М.А. Шапіро, Дж. Р. Браєр та К. Філд у роботі «Карсон МакКаллерс: описовий перелік та анотована бібліографія критики» ${ }^{51}$. Однак на увагу заслуговує передусім студія «Самотній мисливець: біографія Карсон МакКаллерс» $(1977)^{52}$ В.С. Карр. Тут найбільш повно представлена особистість письменниці, всебічно охарактеризовано ii життя й творчість від народження в 1917 році в Колумбусі до смерті в 1967 році в Нью-Йорку. Цей період охопив такі аспекти життєпису, як: а) поява в літературі на рівні сенсації, б) прояви емоційної, художньої та сексуальної ексцентричності, в) виснажливі захворювання; г) подорожі Америкою та Європою; г) еволюційний шлях від перших спроб пера до книжкових видань, сценічних постановок та екранізацій. Значущим інструментом дослідження виступив культурно-історичний метод, у рамках якого доробок К. МакКаллерс трактується як продукт суспільного життя і конкретних культурно-історичних умов. До речі, свою дослідницьку позицію В.С. Карр розгорнула в монографії «Розуміння Карсон МакКаллерс» $(1989)^{53}$, здійснивши комплексний аналіз основних творів мисткині.

${ }^{47}$ Evans O. Carson McCullers, Her Life and Work. London : Owen, 1965. 220 p.

${ }^{48}$ Evans O. The Achievement of Carson McCullers. The English Journal. May, 1962. Vol. 51. No. 5. P. 308.

${ }^{49}$ Edmonds D. Carson McCullers. Austin : Steck-Vaughn, 1969. 43 p.

${ }^{50}$ Graver L.S. Carson McCullers. Minneapolis : University of Minnesota Press, 1969. 48 p.

${ }^{51}$ Shapiro A.M., Bryer J.R., Field K. Carson McCullers: a descriptive listing and annotated bibliography of criticism. New York-London : Garland, 1980. 315 p.

${ }^{52}$ Carr V.S. The lonely hunter: a biography of Carson McCullers. London : Owen, 1977. 598 p.

${ }^{53}$ Carr V.S. Understanding Carson McCullers. Columbia : University of South Carolina Press, 1989. 181 p. 
3'ясування специфіки художнього простору в прозі Карсон МакКаллерс постає безпосереднім предметом вивчення в німецькомовній монографії «Функція простору в оповідній творчості Карсон Мак Каллерс» ${ }^{54}$ Елізабет Вірш-Клінг. Слід відзначити той факт, що дослідниця застосувала інтердисциплінарний підхід, поєднавши результати розвідок у галузі філософії, антропології, фізики, музикознавства, психології та архітектури, а також літературні та лінгвістичні аспекти. На перший план Е. Вірш-Клінг вивела питання відповідності психологічного стану дійових осіб, зосібна в межових ситуаціях, просторовій побудові художньої дійсності на прикладі образів «вікно», «сходи», «двері». Крім цього, в книжці розглядається роль звукового простору (музика, рух, шум, голоси, тиша) як складової частини наративу. Таким чином, ідеться про одну з фундаментальних праць, що віддзеркалюють особливості рецепції К. МакКаллерс поза англомовним середовищем.

Наприкінці XX - початку XXI століть чіткого окреслення набула тенденція пошуку в доробку К. МакКаллерс аспектів рецепції 3 урахуванням новітніх досягнень літературознавства. У монографії «Квітуча мрія: історична сага Карсон МакКаллерс» (1999) ${ }^{55}$ Н.Б. Річ зробила спробу розкрити соціальні та культурні контексти творів «Квітуча мрія», «Серце - самотній мисливець», «Балада про невеселий шинок», «Учасниця весілля», «Квадратний корінь дивовижі», «Годинник без стрілок». Визнаючи «хорошу позицію в південній літературі», дослідниця увиразнила неоднозначності у сприйнятті художньої цілісності прози К. МакКаллерс ${ }^{56}$. Сама ж Н.Б. Річ висловила переконання, що авторка розробила чітку мистецьку стратегію з опертям на мотиви, емоції та поведінкові моделі, поширені на американському Півдні у середині XX століття.

Нові рубежі сприйняття духовної спадщини К. МакКаллерс окреслено в монографії «Дивні тіла: стать та ідентичність у романах Карсон МакКаллерс» $(2003)^{57} \quad$ С. Глісон-Вайт. Австралійська дослідниця закроїла свій аналіз на основі базового для теорії гротеску поняття амбівалентності, а також гендерних та психоаналітичних підходів. Таке новаторське перепрочитання тематики творів крізь

${ }^{54}$ Wirsch-Kling E. Die Funktion des Raumes im Erzählwerk von Carson McCullers. Frankfurt am Main-Berlin-Bern-New York-Paris-Wien : Lang, 1993. 277 s.

${ }^{55}$ Rich N.B. The flowering dream: the historical saga of Carson McCullers. Chapel Hill, NC : Chapel Hill Press, 1999. 131 p.

${ }^{56}$ Rich N.B. The flowering dream: the historical saga of Carson McCullers. Chapel Hill, NC : Chapel Hill Press, 1999. P. 11.

57 Gleeson-White S. Strange bodies: gender and identity in the novels of Carson McCullers. Tuscaloosa : The University of Alabama Press, 2003. 168 p. 
призму гротескної інтерпретації гендерних ролей та статевої ідентичності К. МакКаллерс послужило ще одним доказом того, що мисткиня сприяла формуванню нової парадигми в американському письменстві. У праці С. Глісон-Вайт детально розглянуті сюжети й мотиви іiі творів 3 проєкцією на такі орієнтирні позиції, як: а) труднощі дівчаток підліткового віку в контексті гнітючого існування жіноцтва на Півдні, б) гомосексуальність поза традиційними стереотипами, в) зображення фемінності та маскулінності засобами кроссдресингу, трансвестизму та маскараду, г) ідея провокаційної й динамічної форми гротеску як виклику усталеним категоріям нормальності та ненормальності. Гротеск відіграє символічну роль у прозі К. МакКаллерс, формуючи певною мірою непродуктивний погляд на світ та людські вчинки. Однак той факт, що персонажі та теми текстів К. МакКаллерс створені в 40-х-50-х роках XX століття, тобто в період виникнення напруженості між мінливим статусом жінки та південним ідеалом жіночності, створює особливо благодатне підгрунтя для перегляду цього дискурсу за сучасних умов.

\section{ВИСНОВКИ}

Проведений огляд наукових джерел засвідчує розмаїтість підходів до окреслення комплексу визначальних питань у вивченні творчої спадщини К. МакКаллерс. Їхні виміри охопили проблеми різного рівня, що сприяють об'єктивному розкриттю особливостей поетики американської письменниці, а також основні віхи ії життєвого шляху та світоглядні позиції. Слід відзначити, що найбільш активна фаза критичної рецепції доробку К. МакКаллерс у діахронному й синхронному аспектах припала на 70-90-ті pp. XX століття. Однак саме на зламі епох сприйняття та засвоєння формально-змістових ознак текстових структур авторки роману «Серце - самотній мисливець» набуло якісно вищого рівня, оскільки в основу досліджень лягли сучасні літературознавчі принципи вивчення літератури 3 міжмистецькими зіставленнями. Процес рецепції творчості К. МакКаллерс неоднорідний, а нерідко і суперечливий. Це можна пояснити об'єктивними причинами, що пов'язані з відповідною відмовою наприкінці XX століття від універсального на користь частковому та особливому. Отже, на початку XXI століття, коли вже сформувався загальний погляд на природу творчих устремлінь К. МакКаллерс, з'явилася потреба в деталізації та реінтепретації іiі доробку. У цьому контексті інтерпретація фактологічного матеріалу 3 проєкцією на висвітлення поетики художнього простору в прозі К. МакКаллерс не втрачає свого актуального звучання. 


\section{АНОТАЦІЯ}

У статті зроблено спробу висвітлити особливості рецепції художнього доробку Карсон МакКаллерс, творчість якої вплинула як на розвиток американського письменства, так і на літературний процес другої половини XX століття загалом. Як засвідчив аналіз, парадигма рецепції творчих досягнень К. МакКаллерс у наукових збірниках містить нерідко полярні оцінки й судження. На якісно інший рівень цей дискурс вивели монографії, присвячені поглибленому вивченню художньої спадщини акторки роману «Серце - самотній мисливець». У рецептивному дискурсі особливо вагомим постає хронологічне дослідження життєпису письменниці крізь призму розкриття іiі ідейнохудожньої еволюції. У статті окреслено стан сприйняття та засвоєння прози К. МакКаллерс у сучасному зарубіжному літературознавстві. Визначено основні вектори дослідження творчості мисткині, які й визначають основи для широкої платформи інтерпретацій та трактувань текстів однієї з найбільш оригінальних постатей в американській літературі другої половини XX століття.

\section{ЛIТЕРАТУРА}

1. Barrett E. The "Astonishing Humanity" of Carson McCullers' The Heart is a Lonely Hunter and James Baldwin's Another Country. American Notes and Queries. 2011. Vol. 24. No. 4. P. 216-226.

2. Bell E. Happy objects and cruel optimism in Carson McCullers' story "Correspondence". Short fiction in theory and practice. 2019. Vol. 9. No. 2. P. 117-127.

3. Bell K. Grotesque Encounters with Adolescence: Reading Carson McCullers' The Member of the Wedding. Changing English. 2011. Vol. 18. No. 1. P. 67-73.

4. Bloom H. Introduction. Carson McCullers / ed. by Harold Bloom. New York : Chelsea House Publishers, 1986. P. 1-6.

5. Bloom H. The American canon: literary genius from Emerson to Pynchon / ed. by David Mikics. New York : The Library of America, 2019. $426 \mathrm{p}$.

6. Broughton P.R. Rejection of the Feminine in Carson McCuller's The Ballad of the Sad Cafe. Twentieth Century Literature. 1974. No. 20. P. 33-43.

7. Carlton A. Beyond Gothic and Grotesque: A Feminist View of Three Female Characters of Carson McCullers. Pembroke Magazine. 1988. No. 20. P. 54-62.

8. Carr V.S. The lonely hunter: a biography of Carson McCullers. London : Owen, 1977. 598 p. 
9. Carr V.S. Understanding Carson McCullers. Columbia : University of South Carolina Press, 1989. 181 p.

10. Carson McCullers in the twenty-first century / ed. by A. GrahamBertolini, C. Kayser. Cham : Palgrave Macmillan, 2016. 279 p.

11. Carson McCullers / ed. by Harold Bloom. New York : Chelsea House Publishers, 1986. $159 \mathrm{p}$.

12. Critical Essays on Carson McCullers / ed. by B.L. Clark, M. Friedman. New York : Hall, 1996. 240 p.

13. Davis K., Free W.J. A Thing Known and Not Spoken: Sexual Difference in Carson McCullers Member of the Wedding. The Journal of the Comparative Drama Conference. 1995. No. 16. P. 39-42.

14. Durham F. God and No God in The Heart is a Lonely Hunter. The South Atlantic Quarterly. Fall 1957. No. 56. P. 494-499.

15. Edmonds D. Carson McCullers. Austin : Steck-Vaughn, 1969. 43 p.

16. Edmonds D. Correspondence': A "Forgotten" Carson McCullers Short Story. Studies in Short Fiction. 1972. No. 9. P. 89-92.

17. Evans O. Carson McCullers, Her Life and Work. London : Owen, 1965. $220 \mathrm{p}$.

18. Evans O. The Achievement of Carson McCullers. The English Journal. May, 1962. Vol. 51. No. 5. P. 301-308.

19. Fiedler L. Love and Death in the American Novel. Normal, Il. : Dalkey Archive Press, 1997. 520 p.

20. Fine L. Gender Conflicts and Their "Dark" Projections in Coming of Age White Female Southern Novels. Southern Quarterly. Summer 1998. No. 38. P. 121-130.

21. Free M. Relegation and Rebellion: The Queer, the Grotesque, and the Silent in the Fiction of Carson McCullers. Studies in the novel. 2008. Vol. 40. No. 4. P. 426-446.

22. Gaillard D.F. The Presence of the Narrator in Carson McCullers' The Ballad of the Sad Cafe. Mississippi Quarterly. 1972. No. 25. P. 419-427.

23. Ginsberg E. The Female Initiation Theme in American Fiction. Studies in American Fiction. 1975. No. 3. P. 27-37.

24. Gleeson-White S. A Peculiarly Southern Form of Ugliness: Eudora Welty, Carson McCullers, and Flannery O'Connor. Southern Literary Journal. Fall 2003. Vol. 36. P. 46-57.

25. Gleeson-White S. Revisiting the Southern Grotesque: Mikhail Bakhtin and the Case of Carson McCullers. Southern Literary Journal. Spring 2001. No. 33. P. 108-124.

26. Gleeson-White S. Strange bodies: gender and identity in the novels of Carson McCullers. Tuscaloosa : The University of Alabama Press, 2003. $168 \mathrm{p}$. 
27. Gonzalez C.G. The Intolerable Burden of Femininity in Carson McCullers' The Member of the Wedding and the Ballad of the Sad Cafe. Atlantis: Revista de la Associacion Espanola de Estudios Anglo Norteamericanos. 1994. May-Nov. No. 16: 1-2. P. 133-148.

28. Graver L.S. Carson McCullers. Minneapolis : University of Minnesota Press, 1969. 48 p.

29. Gray R. Review of The Lonely Hunter: A Biography of Carson McCullers, by Virginia Spencer Carr. Journal of American Studies. August 1978. Vol. 12. No. 2. P. 247-248.

30. Groba C.G., Crisler J.S., Cutler E.S. Ivan Ilych in the Jim Crow South: Carson McCullers and Leo Tolstoy. Literature and belief; Belief in the modernist age: a symposium on major novelists. Brigham Young University, 2004. March. P. 117-134.

31. Hubert L. To Alice Walker: Carson McCullers' Legacy of Love. Pembroke Magazine. 1988. No. 20. P. 89-95.

32. Kaiser W. The Micropolitics of Fascism in Carson McCullers's The Heart Is a Lonely Hunter and Sinclair Lewis's It Can't Happen Here. Genre. 2014. Vol. 47. No. 3. P. 285-308.

33. Kestler F. Gothic Influence of the Grotesque Characters of the Lonely Hunter. Pembroke Magazine. 1988. No. 20. P. 54-62.

34. Lubbers K. The Necessary Order: A Study of Theme and Structure in Carson McCullers' Fiction. Jahrbuch für Amerikastudien. 1963. Bd. 8. P. 187-204.

35. Martin R.K. Gender, race, and the colonial body: Carson McCullers's Filipino boy, and David Henry Hwang's... Canadian Review of American Studies. Fall 1992. Vol. 23. No. 1. P. 95-107.

36. Matlok-Ziemann E. Southern Fairy Tales: Katherine Anne Porter's "The Princess" and Carson McCullers's "The Ballad of the Sad Cafe'. The Mississippi quarterly. 2007. Vol. 60. No. 2. P. 257-272.

37. McCullers C. The mortgaged heart... / ed. by M.G. Smith. London : Barrie and Jenkins, 1972. 294 p.

38. McNally J. The Introspective Narrator in The Ballad of the Sad Cafe. South Atlantic Bulletin. 1973. No. 38:4. P. 40-44.

39. Moore J.T. McCullers' The Ballad of the Sad Cafe. Explicator. 1970. No. 29. Item 27. P. 51.

40. Nagpal P. The Element of Grotesque in Reflections in a Golden Eye and Ballad of the Sad Cafe by Carson McCullers. Panjab University Research Bulletin. 1987. October. No. 18:2. P. 61-66.

41. Pachmuss T. Dostoevsky, D.H. Lawrence, and Carson McCullers: Influences and Confluences. Germano-Slavica: A Canadian Journal of Germanic and Slavic Comparative Studies. 1974. No. 4. P. 59-68.

42. Phillips R.S. Dinesen's "Monkey" and McCullers' "Ballad": A Study in Literary Affinity. Studies in Short Fiction. 1964. No. 1. P. 184-190. 
43. Presley D.E. The Moral Function of Distortion in Southern Grotesque. South Atlantic Bulletin. 1972. No. 37:2. P. 37-46.

44. Rechnitz R.M. The Failure of Love: The Grotesque in Two Novels by Carson McCullers. Georgia Review. 1968. Winter. P. 454-463.

45. Rich N.B. The flowering dream: the historical saga of Carson McCullers. Chapel Hill, NC : Chapel Hill Press, 1999. 131 p.

46. Saxton B. Finding Dostoevsky's "Idiot" in Carson McCullers's The Heart Is a Lonely Hunter. American Notes and Queries. 2013. Vol. 26. No. 2. P. 103-108.

47. Shapiro A.M., Bryer J.R., Field K. Carson McCullers: a descriptive listing and annotated bibliography of criticism. New York-London : Garland, 1980. 315 p.

48. Sosnoski K. Society's Freaks: The Effects of Sexual Stereotyping in Carson McCullers' Fiction. Pembroke Magazine. 1988. No. 20. P. 82-88.

49. Spivak G.Ch. Three Feminist Readings: McCullers, Drabble, Habermas. Union Seminary Quarterly Review. 1979-1980. No. 35. P. 1-2.

50. Thurschwell P., Hurley N. Dead Boys and Adolescent Girls: Unjoining the Bildungsroman in Carson McCullers's The Member of the Wedding and Toni Morrison's Sula. English studies in Canada. 2012. Vol. 38. No. 3/4. P. 105-128.

51. Über Carson McCullers / Hrsg. von G. Haffmans. Zürich : Diogenes, 1974. $221 \mathrm{~S}$.

52. Walsh M. Carson McCullers' anti-fairytale: "The Ballad of the Sad Café". Pembroke Magazine. 1988. No. 20. P. 43-49.

53. Wirsch-Kling E. Die Funktion des Raumes im Erzählwerk von Carson McCullers. Frankfurt am Main-Berlin-Bern-New York-ParisWien : Lang, 1993. 277 S.

54. Wu C. Expanding Southern Whiteness: Reconceptualizing Ethnic Difference in the Short Fiction of Carson McCullers. Southern Literary Journal. 2001. Vol. 34. Part 1. P. 44-55.

55. Young M. Metaphysical Fiction. Critical Essays on Carson McCullers / ed. by B.L. Clark, M. Friedman. New York : Hall, 1996. P. 34-37.

\section{Information about the author: Mandzyuk R. S.,} Lecturer at the Department of the Theory and Practice of Translation of the Faculty of International Economic Relations

Uzhhorod National University 14, Universytetska str., Uzhhorod, 88000, Ukraine 